\title{
Toxoplasma gondii infection in immunocompromised individuals
}

\author{
Andrei Csep *, Sonia Drăghici \\ From The 9th Edition of the Scientific Days of the National Institute for Infectious Diseases Prof Dr Matei Bals \\ Bucharest, Romania. 23-25 October 2013
}

\section{Background}

Toxoplasmosis is a parasitic zoonosis, caused by protozoan Toxoplasma gondii.

\section{Method}

Using the CLIA (chemiluminescence immunoassay) method we determined the IgM and IgG Toxoplasma gondii antibodies, and by the EIA (enzyme immunoassay) method the IgA Toxoplasma antibodies in HIV infected persons in Bihor County, during the year 2012.

\section{Results}

The study included 30 patients, with HIV infection, 26 $(86.7 \%)$ of them with antiretroviral treatment, while 4 (13.3\%) of them without treatment. Two patients $(6.66 \%)$ without antiretroviral treatment were found with protective antibody for Toxoplasma gondii, while 8 (26.66\%) patients with antiretroviral treatment were found with the same antibodies. Two cases from the last category $(6.66 \%)$ were diagnosed with acute forms of the disease, in which we found IgM to IgG toxoplasma seroconversion.

The seroprevalence of Toxoplasma gondii antibodies in HIV infected patients was $33.3 \%$.

\section{Conclusions}

The obtained value (33.3\%) in our study is approximately similar to results reported on seroprevalence of Toxoplasma gondii antibodies in researches with similar purpose. This high percentage proves that Toxoplasma gondii is an additional risk factor for immunosuppressed patients.

Published: 16 December 2013

\footnotetext{
* Correspondence: csep.andrei@gmail.com
} University of Oradea, Romania

(c) 2013 Csep and Drăghici; licensee BioMed Central Ltd. This is an Open Access article distributed under the terms of the Creative Commons Attribution License (http://creativecommons.org/licenses/by/2.0), which permits unrestricted use, distribution, and reproduction in any medium, provided the original work is properly cited.
doi:10.1186/1471-2334-13-S1-P4

Cite this article as: Csep and Drăghici: Toxoplasma gondii infection in immunocompromised individuals. BMC Infectious Diseases 2013 13(Suppl 1):P4.
Submit your next manuscript to BioMed Central and take full advantage of:

- Convenient online submission

- Thorough peer review

- No space constraints or color figure charges

- Inclusion in PubMed, CAS, Scopus and Google Scholar

- Research which is freely available for redistribution
- Immediate publication on acceptance

\section{Biomed Central}

